\title{
Warga Peduli AIDS': Community Participation in The HIV and AIDS Response in Bandung
}

\author{
ERNA HERAWATI \\ Department of Anthropology, Faculty of Social and Politic Science, Universitas Padjadjaran \\ email: e.herawati@unpad.ac.id
}

\begin{abstract}
Human immunodeficiency virus (HIV) becomes the global epidemic. It attacks human immune system, and if left untreated it leads to AIDS (acquired immunodeficiency syndrome). Indonesian governmental and non-governmental institutions are the main actors in the response to this epidemic since late $80 \mathrm{~s}$, while community participation has newly emerged. This study discusses 'Warga Peduli AIDS' (local residents concerned about AIDS) in Bandung, which is one of the rare forms of community participation in the HIV and AIDS response in Indonesia. Using ethnographic method, this study examines the main actions by Warga Peduli AIDS, such as attendance in HIV related meetings, events, and workshops; dissemination of information; and provision of support and companionship for neighbours living with HIV. This study finds that members of the community actively participate in the HIV and AIDS response through their actions as Warga Peduli AIDS, and their actions has contributed significantly to the national strategies to respond the HIV and AIDS in Indonesia
\end{abstract}

Keywords: HIV, AIDS, community, response

\section{Introduction}

Indonesia has been experiencing HIV and AIDS for three decades since 1987 when the Indonesian Ministry of Health officially reported the first case to the public. Since then, many stakeholders have started to respond to the situation. The major responses to the epidemic come from government and international non-government organizations (NGO), while private organisations and the community have taken a less responses. The responses by the government and nongovernment organisations have generally been formal programs which design and model refer to the guidelines prescribed by United Nation of AIDS (UNAIDS) and World Health Organisation (WHO) with some modification to adjust them for the local situation. The programs are implemented through a 'topdown' approach and focus on preventive and curative programs that follow a biomedical approach, which aims at increasing the early detection of cases and at improving early treatment for those who are infected. In this type of program, members of the community are involved as passive recipients and the targets of the programs.

Responses by the private sector are still limited but are starting to increase. In 2004, the Ministry of Workforce promulgated regulations regarding HIV prevention in the workplace that mandated private sector initiatives, particularly from private companies, to take part in the response to the epidemic. The Indonesian Business Coalition on AIDS, formed in 2007, is one example of a response from the private sector. Some of the actions by this sector include prevention campaigns aimed at employees and provision of funding for prevention programs in the community through corporate social responsibility schemes. One of the examples of this action is by PT Freeport Indonesia which set up a sexually transmitted disease clinic in Timika and carried out program to educate and encourage members of the community to undertake voluntary counseling and testing for HIV. Private organizations follow the format of formal programs in collaboration with government or non-

Received: May 01, 2017, Revision: August 28, 2017, Accepted: December 13, 2017

Print ISSN: 0215-8175; Online ISSN: 2303-2499. DOI: http://dx.doi.org/10.29313/mimbar.v33i2.2439.319-328

Accredited B based on the decree No.040/P/2014, valid on February, 18, 2014 until February, 18, 2019. Indexed by DOAJ, Sinta, IPI 
government organizations. Some of the programs involve workshops and training for employees to create awareness and to improve knowledge and understanding about the epidemic, to eradicate or reduce the stigma of HIV and AIDS, and to encourage early HIV testing (Company-Community Partnership for Health in Indonesia 2012; Indonesian Business Coalition on AIDS, 2014).

People who are not infected nor directly affected usually have a negative view of the epidemic, and negative view of the people who are affected and infected. Such people tend to avoid people living with HIV and their families and are reluctant to discuss the epidemic or to take part in any activities that might help to ameliorate the situation. In short, most people do not see the issue as part of their own sphere of interest and they leave it to the government and nongovernment organizations to deal with it. Despite the general misgivings in the community, there are some people or groups that have overcome the fears and prejudice.

Groups of women in the Indonesian city of Bandung have pioneered a communitybased approach to the management of HIV and AIDS in their residential communities since 2006. These local residents and their actions are known as Warga Peduli AIDS (local residents concern about AIDS). This has become the first form of community action and participation to respond HIV and AIDS in Indonesia and it was officially recognized by the Indonesian National AIDS Commission in 2010 (Komisi Penanggulangan AIDS Nasional, 2010).

Community action to respond HIV and AIDS is a new phenomenon in Indonesia and it is not yet well developed. The newness of this type of community response is understudied in Indonesia. The responses by the community are commonly informal and voluntary actions by community members who are concerned about the epidemic and their good works are carried out in groups or individually. Their actions usually take a 'bottom-up' approach in which the community members become the initiators, planners, and actors. Their focus is usually on the non-biomedical aspect of the epidemic, such as ameliorating the effect of the epidemic on social, cultural or economic life; on actions to increase community awareness of the epidemic; actions to reduce the stigma and discrimination that infected people suffer from; and on providing social support for them.

This study examines actions by Warga Peduli AIDS in order to demonstrate how these actions illustrate community participation in response to the HIV and AIDS in Indonesia, and how the actions have contributed significantly to the effectiveness of the response.

\section{Research Method}

This study applied qualitative approach, in particular ethnographic method. Ethnography originally is one of qualitative research method which aims to describe a culture in order to understand a way of life from the native point of view (Spradely, 2016). Ethnography used to be identical with Anthropology but today this method has been widely used in many disciplines in order to describe the case comprehensively from the actors' point of view.

The fieldwork was conducted in two rounds: August 2012 to March 2013 and December 2015 to March 2016. The researcher has established network with Warga Peduli AIDS activists since 2009. Trust and good rapport between the researcher and the activists has been built since then as both engaged in some HIV prevention and intervention program in Bandung. The data collection for this study included participant observation and in-depth interviews

Sample for this study was chosen purposively: three Warga Peduli AIDS groups at three kecamatan (sub-district), which are Rancasari, Sumur Bandung, and Batununggal. These groups were the most active in Bandung. The group at Rancasari is known for its 'well-organized' group. It takes the format as formal organization with wellstructured board members. It has a complete documentation of actions. The group at Sumur Bandung is known for its provision of support and companionship to people living with HIV. Meanwhile, the group at Kecamatan Batununggal is known as the 'oldest' group in Bandung because the activists have been involved in the action since 2008.

Interviews were conducted to 30 activists of three groups and were recorded upon the permission of the activists. The recordings then were transcribed and organized in a matrix of findings (Miles and Huberman, 2009) for thematic analysis.

Data in this study were presented using emic perspective following the principal 
of ethnographic writing (Hammersley and Atkinson, 2007; Van Maaneen, 2011). Pseudonym is used for all the activists participated in this study in order to protect their confidentiality.

\section{Literature Review}

The importance of community participation in the effectiveness and the success of community development have been widely studied. Akadun (2011) study is one example on how the community participation is crucial for community development. He gives an example of the community participation in the Musyawarah Rencana Pembangunan (Meeting for development planning) to voice their aspiration which is crucial for local development planning. This helped the local government to draft a development design which fits the community needs and suits the local situation.

In the context of HIV and AIDS, community participation is also crucial in the success of response, particularly in highly affected countries. Responses from community members are the most effective because they understand their local context, so can tailor their methods and activities as necessary (Chillag, 2002; Kabore et al., 2010; Thomas-Slayter \& Fisher, 2011; Michael, et al., 2012;). Community responses also have special features: they cost less, are based on local needs and available resources, and enjoy the understanding and support of community members. Community participation in the response to HIV has been increasingly identified as a 'critical enabler' for effective measures against HIV/AIDS (RodriguezGarcia et al., 2011; Schwartlander et al., 2011).

Community participation in the HIV and AIDS response is also an indication of the 'community competency'. This concept refers to a community whose members are likely to collaborate in responding effectively to HIV and AIDS. This type of community is characterized by opportunities for dialogue about HIV and AIDS with its members. This dialogue then ideally leads the community members to share their HIVrelated knowledge; to critically think about the obstacles to health-enhancing behaviour changes and obstacles to discussions of locally realistic strategies for tackling HIV and AIDS; to develop their sense of local ownership and responsibility for contributing to the struggle against HIV and AIDS rather than passively relying on government and NGOs; to identify individual and group strengths for this challenge; to bond social capital (such as a sense of solidarity and common purpose in relation to tackling HIV and AIDS); and to bridge social capital (such as to link with supportive external groups in the public, private and NGO sectors) for their response (Campbell, 2007; 2013).

Despite the significant contribution, community participation receives little attention from government and international agencies. Only recently, they have some government and international donor institutions acknowledged the contribution of this community participation, particularly on its ability to fit with the local context and to ensure the sustainability of human resources to address HIV and AIDS (Rau, 2006; Reid, 2010).

\section{HIV and AIDS Situation in Bandung}

Bandung City Health Office reported the first HIV and AIDS case in Bandung in 1991, only a few years after the Ministry of Health officially reported the first case in Indonesia in 1987 (Komisi Penanggulangan AIDS Kota Bandung, 2010). The number of people infected by the virus keeps increasing since then. Bandung City AIDS Commission reported 1949 people in Bandung are living with HIV and 1576 living with AIDS, therefore a total 3525 people living with HIV and AIDS by 2015 . This number is about $1 \%$ of the total population of Bandung. In terms of demographic characteristics, people living with HIV and AIDS in Bandung majority are male $(64.98 \%)$, who are at their reproductive age $(48.65 \%$ are $20-29$ years old and $33.65 \%$ are $30-39$ years old), and who are at the working force $(76.22 \%$ of them hold a job). These demographic characteristics indicate the potential impact that HIV could bring to household and to social and economic aspect of the society (Komisi Penanggulangan AIDS Kota Bandung, 2015). Recently, Bandung AIDS Commission reported the increasing number of women who become HIV positive. The women get the infection from sexual contact with their husband, whom without their knowing is HIV positive. The increasing numbers of women who are HIV positive is likely to increase the number of babies who are born with HIV positive. Bandung City Health Office recorded 214 children under five years old and 77 children age $5-14$ years living with HIV by 2015 . They come from family living with HIV (Kurniawan, 2015). All 
of these data illustrate the alarming situation of HIV in Bandung.

HIV does not merely bring health impact to the city population who are infected and affected, but also brings a sociocultural and economic impact. Stigma has become the sociocultural issue that causes a huge problem for people living with HIV. Stigma leads to discrimination and marginalization of people living with HIV or AIDS and their families in the community and it also affects their economic situation. Many people living with HIV have to give up their employment because of their HIV status; not because of their physical condition but because of stigmatization and discrimination from their employer and coworkers (Nurhayati, 2012; Shaluhiyah, 2015). As the new HIV infection keeps increasing, the impact of the epidemic to everyday life of infected people is exacerbating. A collaborative work which includes key actors, government, non-government organizations, and community is strongly needed; not only to respond the biomedical impact but also the sociocultural impact. However, in any collaborative work, only government and non-government organizations commonly involved; while the community often left behind. Furthermore, the stigma of HIV in the community as a 'curse' and a 'dirty' disease often made community reluctant to participle in the response.

The negative image of HIV and AIDS roots in the community belief about the diseases as the result of a practice 'against the social norms' such as homosexuality and prostitution. This image has shaped the common perception and moral standard towards the disease and the sufferers and such stigma is very hard to dispel from the community; despite the fact that people has obtained sufficient knowledge and information about the epidemic. The majority of community members usually react to HIV and AIDS with fear because of the stigma and consequent discrimination (Harapan et al., 2013). People who are not infected nor directly affected by HIV usually have a negative view of the epidemic and of the people who are affected and infected (Massie, 2012). They tend to avoid the victims and their families and are reluctant to discuss the epidemic or to take part in any activities that might help to ameliorate the situation. In short, most people do not see the issue as part of their own sphere of interest and they leave it to NGOs and the government to deal with it.
The Warga Peduli AIDS groups in Bandung (known by its abbreviation WPA), however, demonstrates a different type of community response. Instead of ignoring the HIV and AIDS issue and avoiding people living with HIV, the activists of Warga Peduli AIDS actively share information about the epidemic, promote anti-stigma and antidiscrimination, and provide social support to their neighbours who are living with HIV. The activists of this action successfully bring the HIV issue closer to the community. They could communicate relevant informations about the epidemic in ways that their neighbours easily understood and aware of its relevance to their everyday life. The actions by the Warga Peduli AIDS activists also have helped infected and affected people to cope with their disease, to alleviate social burden and to gain better quality of life. The action by the Warga Peduli AIDS in Bandung is therefore a very interesting societal phenomenon in the context of HIV and AIDS response in Indonesia because this type of action is still very limited and also quite unusual. As a new types of response, however, very little is known about Warga Peduli AIDS outside the groups involved and there has been no academic research so far on this type of grassroots activism in Indonesia.

\section{The Warga Peduli AIDS}

In Bandung, many local residents become concern about the HIV epidemic as they receive information about the epidemic from NGOs activists working on HIV prevention in Bandung and as they witness neighbours suffering from the disease. In 2006, they decided to form a group and to initiate actions to articulate their concerns about HIV and AIDS since 2006. They named themselves and their actions Warga Peduli AIDS, abbreviated to WPA.

In 2010, Bandung City AIDS commission facilitated the formation of Forum Warga Peduli AIDS in every sub-district (kecamatan). This Forum then fostered the emergence of several new Warga Peduli AIDS groups. Since then, almost every "kelurahan" in Bandung form Warga Peduli AIDS. Some activists conduct their actions individually, while others living in the same residential area form groups and do things collectively.

Working in their own residential areas does not mean that each activist is isolated from each other. They establish networks with members of other kelurahan and kecamatan. 
When they meet, they get updates about each other's works. They also building network with people working on HIV/AIDS in Bandung, such as NGO activists, staff of the Bandung City AIDS Commission, staff of the City Health Office and so on. They utilize these networks to get information about events and programmes in which they could participate and to get support for their action. The activists do not implement the formal programmes of the City Government or Bandung City AIDS Commission, even though there is cooperation. They design their own types of action and choose the methods to deliver it by themselves, based on their skills and the situation in their residential area. Therefore, there are various types and methods of action across kelurahan and kecamatan.

Warga Peduli AIDS has similar characteristic with other format of community based action, such as Posdaya. Posdaya tends to be independence and self-reliance; and its success and failure lies on the willingness of the people to move forward, not by the amount of fund or material inventory (Sadono et al., 2017). As a grass root initiative, the sustainability of Warga Peduli AIDS determine by the willingness of its activists to carry out this voluntary initiative.

Table 1

Warga Peduli AIDS's activities

\begin{tabular}{|c|c|}
\hline Activities & Detail of activities \\
\hline $\begin{array}{l}\text { Participation in } \\
\text { HIV meeting and } \\
\text { events }\end{array}$ & $\begin{array}{l}\text { Participate in regular } \\
\text { events ( Hari AIDS } \\
\text { Sedunia and Malam } \\
\text { Renungan AIDS) ; } \\
\text { Participate in incidental } \\
\text { events (workshop and } \\
\text { trainings, jambore, } \\
\text { expos) }\end{array}$ \\
\hline $\begin{array}{l}\text { Dissemination of } \\
\text { information }\end{array}$ & $\begin{array}{l}\text { Disseminate information } \\
\text { to neighbours (adult and } \\
\text { youth) in formal and } \\
\text { informal meetings }\end{array}$ \\
\hline $\begin{array}{l}\text { Pendampingan / } \\
\text { companionship }\end{array}$ & $\begin{array}{l}\text { Accompany neighbours } \\
\text { living with HIV and AIDS } \\
\text { to access treatments } \\
\text { Provide emotional } \\
\text { support to neighbours } \\
\text { living with HIV and AIDS } \\
\text { Assist some female } \\
\text { neighbours living with } \\
\text { HIV and AIDS to access } \\
\text { livelihood support }\end{array}$ \\
\hline
\end{tabular}

Source: Field data

\section{The Actions}

The actions by Warga Peduli AIDS can be differentiated into three general forms: (1) participation in events; (2) information dissemination; and (3) pendampingan or companionship. Participation in events and information dissemination are the most common actions, while companionship is the least common. Companionship is an action in which activists establish close networks with people living with HIV, in order to accompany them to antiretroviral therapy and provide emotional support. Companionship also refers to activists establishing close networks with members of the key population (people who inject drugs, transgender, gay, and sex workers) in order to encourage them to perform HIV prevention. Only a few activists engage in companionship actions because they require trust between them, people living with HIV and members of the key population (see Table 1).

\section{Participation in HIV meeting and events}

Most Warga Peduli AIDS activists mentioned that HIV and AIDS were topic they knew little about, and therefore they needed to learn a lot. Once they had a complete understanding of it they would be able to relay information confidently to neighbours and acquaintances. Therefore, they actively participate in events to enhance their knowledge, such as meetings, training courses and workshops on HIV. The events are hosted by various institutions, governmental and non-governmental, working on HIV prevention.

The activists build networks with the staff of these institutions and ask them to share information about events and meetings. Neneng Lestari, the activist of the WPA group at Rancasari mentioned that being part of a network of people who work in HIV prevention has helped her finding the best role and contribution of WPA to best respond to the epidemic. She asserted that as a grassroots organization, the WPA has the important role of ensuring that local residents pay attention to AIDS and to encourage them to take active responses. She admitted that they could learn from brochures or leaflets received during meetings, but that is not enough because this does not allow for discussion or confirmation of information. In meetings, activists can learn about the most recent cases in Bandung. 
The meetings attended by activists are both formal and informal. NGO activists often host informal meetings and invite activists in their network. Besides meetings, activists also participate in two annual HIV events: the Malam Renungan AIDS or Candlelight Memorial in May, and Peringatan Hari AIDS Sedunia, or World AIDS Day, in December. The World AIDS Day event is the biggest HIV event, joined by all people working on HIV/ AIDS. The activists also participated in some occasional events such as Jamboree Warga Peduli AIDS, Expo Warga Peduli AIDS hosted by Bandung City Government and Bandung AIDS Commission.

\section{Dissemination of Information}

Conveying information about the HIV epidemic has become the most common action undertaken by WPA activists, aside from participation in events related to HIV, known as sosialisasi HIV or penyuluhan HIV) which means publicizing information about HIV. The information includes the features of the disease, how it is transmitted and how it might be prevented, treated and patients cared for. Activists have much the same reasons for engaging in these activities: the urgent need to disseminate information. According to them, many HIV-positive people in Bandung learn about the disease after they have become infected, which is too late. They assume that if people have prior knowledge, they would know if they are at risk and would have the chance to take preventive action. Another reason for activists to disseminate information is to remove misconceptions and reduce pervasive stigma.

Stigma about HIV and AIDS is pervasive in Bandung. Stories about people living with HIV being evicted by their family, people living with HIV being terminated from their job contract by their employer, or a student living with HIV being asked to leave school are common in Bandung. According to the WPA activists, people's lack of knowledge and understanding about the disease made them develop the stigma towards people suffer from the disease. They also mentioned that the epidemic today does not only infect people with specific behaviours, such as people who inject drugs, people who sell sex service, or people who have non-heterosexual orientation, but it does infect all members of the community. Besides, the disease is blood-borne disease and therefore the transmission of the virus is not as easy as air-borne and water-borne disease. Based on these knowledge and understanding, the WPA activists aim to disseminate information to people in order to give sufficient knowledge about the epidemic which later on could reduce people's stigma towards it.

Even though all activists disseminate information, the methods they use differ depending on their skills and the target. For example, a skillful activist tends to use more creative methods of communication. Other activists use more than one method, depending on the audience, such as altering their approach depending on the age and sex of the group. However, apart from the variety of methods of conveying information, most activists tend to integrate their dissemination of information with other activism.

Maryam Suminar is an activist at Rancasari who integrates her action to disseminate information about HIV and AIDS with her activities as leader of Rukun Warga Siaga (RW Siaga), or the alert community group. HIV/AIDS has been one of the health problems dealt with by the RW Siaga programme; others are nutrition and various other communicable diseases, sanitation and hygiene. One of her actions was to organize a meeting about HIV/AIDS for local residents of her RW. She designed the meeting as a talk show about HIV/AIDS. She invited guest speakers who are expert in HIV and AIDS, such as the Secretary of Bandung AIDS Commission, a midwife from the Puskemas at Kecamatan Rancasari, an ustadz (Islamic teacher) from other kecamatan who is also Warga Peduli AIDS activists, and a person living with HIV who is the local resident of Rancasari. According to Maryam, she preferred the format of talk show over a formal meeting because informal meetings are usually more effective at delivering information. Audiences usually engaged more in informal discussions. The meeting took place at the mosque and received much attention from the local residents: hundreds of people (young and old, male and female) attended. The topic was new to them and they were keen to learn. The meeting also gave them a new experience: meeting a person living with HIV during the testimony session. The speakers fielded many questions from the audience, and the meeting lasted for three hours, an hour longer than scheduled.

The talk show was reported in a local magazine published by one of the RW in Rancasari to cover local activities. At the talk show, Maryam noted that people in her 
residential area were keen to learn about the epidemic as they lacked knowledge. Based on her observations about the issue, she was motivated to do something regularly to educate them. She wanted them to have sufficient knowledge and to be concerned about the problem. Before she took any action, she collected the most recent information about the epidemic in Bandung and West Java.

Neneng Zubaidah, another activist at Rancasari began a regularly activity to distribute information to people in her RW. She started with two intensive activities in her RW, Posyandu (Pos Pelayanan Terpadu [Integrated Health Post]) and PKK (Pemberdayaan Kesejahteraan Keluarga [Family Welfare Movement]) meetings. During the lunch breaks of Posyandu meetings, Neneng invited the health volunteers to discuss the epidemic. She also did this at PKK. Her discussions made her realize that almost all health volunteers had no knowledge of HIV/AIDS but many misconceptions about it. At her information sessions, Neneng does not use brochures or leaflets, only giving a short talk. In some other Posyandu she received good feedback from the health volunteers, who asked her for written material to help them understood important information that was new to them. Such material would make it easier for them to relay information to their social circles. Neneng said she would do what she could to obtain and distribute relevant.

In Kecamatan Batununggal, Farida Rahmawati, one of the activists there, actively disseminate information to women and young people. The fact that more women and children are becoming infected, and that more young people engage in sexual activities leading to HIV infection, has made her restless. She worries whether she is at risk, too, as her husband works out of town and she wonders whether he remains faithful. Although she believes in her husband's fidelity, she still worries about him. She learned that daily conversation, particularly among people in her neighbourhood, was a potential venue for passing on information. Every afternoon, a group of women meet at a house very close to hers. She uses some printed material, brochures and other hand-outs from the workshop she attended to help her gave the information. She also gave information at Karang Taruna (Youth Organisation) at Batununggal. Her speaking style was simple, direct and at times jocular, to ensure that her audience paid attention.
The young people were very interested and asked that she organize another meeting for them to continue the discussion. The success of the meeting with the young people encouraged Farida to continue her efforts.

\section{Companionship (Pendampingan)}

Most WPA activists in Bandung focus on delivering information and only a few provide pendampingan or companionship, where they accompany people living with HIV when accessing treatment and livelihood support, or when handling problems related to their HIV status, providing emotional support whenever needed. Companionship actions require trust between activists and the people they are helping. Warga Peduli AIDS at Kecamatan Sumur Bandung is the only group in Bandung which focuses on this activity. The activists at this kecamatan stated that they choose to focus on pendampingan because many of their neighbours are living with HIV.

Prior to their WPA activism the activists at this kecamatan were health volunteers who dealt with health and related matters, including how to benefit from public health services. The work they do ranges from accompanying ill people to hospital to helping poor people know their entitlements and how they can use and benefit from free health services. It is common for them to accompany the sick during hospital stays as a patient's family often requests this. Most local residents do not have any experience of hospital procedures, and they ask the activists to become mediators with health service providers. In many cases, activists also authorize decisions on behalf of the family whenever medical staff need consent. The activists continued this work when they became WPA activists. They often bring people living with HIV to hospital, and know the treatment they need. Besides accompanying people to the hospital, WPA activists also accompany those undergoing ARV therapy to collect medicine regularly from the hospital.

Linda Rahman, one of the activists at this kecamatan said that HIV-positive patients lack confidence when speaking to doctors about their therapy. It is common that they forget to take their pills or are careless about their medical schedules, and these difficulties can be attributed to work or family situations. However, they do not dare explain their situation to doctors and nurses in the hospital. They have often told her that the doctors and nurses in hospitals accused them of laziness and are condescending, which is why they ask her to accompany them to collect medicine and to help them discuss their condition with a doctor. It is 
also common that they are unwilling to tell the doctor about their experience with ARV therapy. The activists also establish networks people who inject drugs in Sumur Bandung and attempt to persuade them to take HIV tests and attempt HIV prevention.

Activists at Kecamatan Sumur Bandung do not only help to treat people with HIV, but also help them get welfare benefits. In 2012, they assisted three widows living with HIV to receive funds from the City Welfare Office. Activists heard of their plight from one of the BCAC's staff. They wrote successful proposals for funding application on behalf of the widows. Each woman received IDR $5,000,000$, about AUD500.00. The funding was to help them start or improve a micro business. One already had a business selling snacks in front of the elementary school in the kecamatan and used the money to repay debts. Another woman found a permanent job soon after receiving the benefit and put the money into a savings account. The third woman started a business of selling milk.

\section{Table 2 \\ Government/Non-government organizations vs Warga Peduli AIDS}

\begin{tabular}{|c|c|c|}
\hline & $\begin{array}{l}\text { Government } \\
\text { \& Non- } \\
\text { government } \\
\text { organization }\end{array}$ & $\begin{array}{l}\text { Warga Peduli } \\
\text { AIDS }\end{array}$ \\
\hline Model & $\begin{array}{l}\text { Top down, } \\
\text { formal }\end{array}$ & $\begin{array}{l}\text { Bottom-up, } \\
\text { informal }\end{array}$ \\
\hline Focus & $\begin{array}{l}\text { Biomedical } \\
\text { (prevention } \\
\text { through harm } \\
\text { reduction: } \\
\text { reduce virus } \\
\text { transmission) }\end{array}$ & $\begin{array}{l}\text { Non-biomedical } \\
\text { (building } \\
\text { awareness } \\
\text { to increase } \\
\text { concern and } \\
\text { actions for } \\
\text { prevention; } \\
\text { decrease } \\
\text { stigma) }\end{array}$ \\
\hline $\begin{array}{l}\text { Working } \\
\text { strategies }\end{array}$ & $\begin{array}{l}\text { Improve } \\
\text { services for } \\
\text { HIV and AIDS } \\
\text { related health } \\
\text { services, } \\
\text { expand } \\
\text { program to } \\
\text { reach out 'key } \\
\text { population' }\end{array}$ & $\begin{array}{l}\text { Participation in } \\
\text { HIV and AIDS } \\
\text { related events, } \\
\text { dissemination } \\
\text { of information, } \\
\text { companionship }\end{array}$ \\
\hline Target & $\begin{array}{l}\text { 'key } \\
\text { population' : } \\
\text { people who } \\
\text { inject drugs, } \\
\text { sex workers, } \\
\text { transgender, } \\
\text { men who have } \\
\text { sex with men }\end{array}$ & $\begin{array}{l}\text { 'general } \\
\text { population' (all } \\
\text { members of the } \\
\text { community) }\end{array}$ \\
\hline
\end{tabular}

Source: Field data

\section{The contribution of actions to HIV and AIDS Program}

The actions by WPA activists and their approaches are different from those of other NGOs. WPA activists target all members of the community, not only specific groups that are considered the key population, while NGOs focus on the latter. This means that the WPA activists' reach is larger than that of NGOs. Further, WPA activists' actions address more the social aspect of the epidemic. For example, companionship does not just increase prevention, but mitigates the social impact of the epidemic.

Through this action, activists help people living with HIV and members of the key population to improve their biological and social quality of life. They provide emotional and financial support.

The different approach between government and non-government programs in the Warga Peduli AIDS could be summarized as Tabel 2.

Some studies have found that community participation in programs and activities to mitigate and eradicate the deleterious effects of HIV and AIDS have made a significant contribution to their effectiveness (Beeker, Guenther-Grey and Raj, 1988; Peersman et al., 2009). In Indonesia, discussion about encouraging community participation in the HIV response has become more prominent in recent years. The Indonesian National AIDS Commission has included community participation in its National Strategy and Action Plan 2010-2014 (Komisi Penanggulangan AIDS Nasional, 2010).

This study has described how the Warga Peduli AIDS actions show community participation in HIV and AIDS response and also demonstrate community members' capability and critical thinking in response to the epidemic. These are shown in the actions they choose to undertake and their methods, how they design their actions and the way they resolve obstacles. Instead of following the international guidelines on intervention, the activist of WPA design their own activities. Despite its small size, it does not mean that this community response does not contribute significantly. The actions by the Warga Peduli AIDS have contributed to the national HIV and AIDS strategy program in Indonesia. The summary of the WPA contributions is shown in figure 1 .

The activists' participation in HIV/ AIDS-related events is an effort by the 
activists to build their capacity to respond to the epidemic; they improve their knowledge and locate themselves in the network of people and institutions working on this issue. This effort is very important for them to be confident in their actions. They build their capacity by joining events; and networking also reinforces their concern about the issue. The more they participate in events, the more concerned they become.

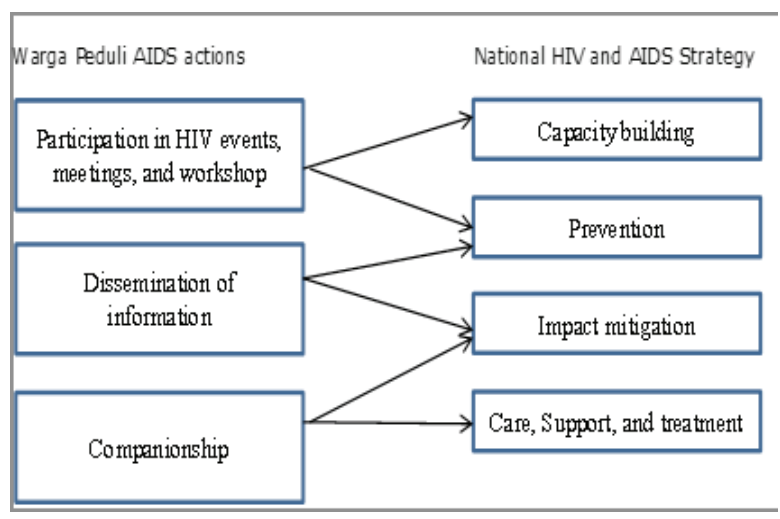

Figure 1. Warga Peduli AIDS Contributions to National HIV and AIDS strategy

Furthermore, meetings and events have become a space where activists have the opportunity to discuss the epidemic and to endorse prevention. This space is crucial for them in building their competency to respond to the epidemic.

Dissemination of information by the WPA activists has improved the knowledge of neighbours who receive the information and gradually led them to do some prevention. This action also encourages impact mitigation, especially stigma reduction. Adequate knowledge about the epidemic may decrease people's stigma towards it.

Companionship also reduces stigma among the member of community. The activists bridge the social interaction between people living with HIV and the community, and attempt to ensure the community about the importance to support the sick despite the stigma. Companionship contributes the most to care, support and treatment for people living with HIV and AIDS. The actions by activists at Kelurahan Kebon Pisang are the example of this case. They accompanied people living with HIV to access treatment and care, as well as to provide them emotional support.

Although the Warga Peduli activists in Bandung successfully help people affected by the epidemic, they also face some obstacles. Not all people in Bandung appreciate their actions. In Kecamatan Sumur Bandung for example when an NGO from Jakarta heard about their actions and made a documentary movie about them, some local residents accused them of searching for popularity through others' suffering. At first, they were upset to hear such comments, but later they decided to disregard them and continue their actions.

Activists also face obstacle from the people they work with. Not all local residents see the importance of the activists' work, and therefore do not want to listen to their information. Not all people living with HIV or members of the key population want to be approached and assisted by activists, as they do not want to be visible and attract stigma and discrimination. Sometimes, these people respond negatively to activists. Such obstacles do not discourage the activists, as they take them as a challenge.

\section{Conclusions}

The WPA actions are original and sustainable. Unlike the actions driven by projects and financially support by donors, which tend to stop when a project finishes, the WPA activists' actions tend to last longer because they are driven by awareness and concern about the epidemic, and such concerns have been reinforced through intensive actions. The sense of ownership and responsibility towards the epidemic is also reproduced. According to the activists, all their work is considered very important because it proves their concern and contribution to the response.

Response to HIV and AIDS needs a strong collaboration between government and non-government organization and community. Warga Peduli AIDS is one of the formats of community participation to respond HIV and AIDS in Indonesia that is proven to be suitable and effective in Bandung. However, little has been known about the possibility to scale up this format of action in other setting in Indonesia. Therefore, further studies about this format of action and the possibility to scale up this format is needed to encourage higher participation from the community in the HIV and AIDS response in Indonesia.

\section{References}

Akadun, A. (2011). Revitalisasi Forum Musrenbang sebagai Wahana Partisipasi Masyarakat dalam Perencanaan Pembangunan Daerah. MIMBAR Jurnal Sosial dan Pembangunan, Vol. 27, No 2: 181-191 Desember 2011.

Campbell, C., Nair, Y., \& Maimane, S. (2007). Building Context that Support Effective 
Community Response to HIV/AIDS: A South African Case Study.American Journal of Community Psychology, Vol.22 No 2: 347-363.

Campbell, C., Nhamo, M., Scott, K., Madanhire, C., Nyamukapa, C., Skovdal, M., et al. (2013). The Role of Community Conversations in Facilitating Local HIV Competence: Case Study from Rural Zimbabwe. BMC Public Health. Vol.12 No. 1: S114-S112.

Chillag, K., Bartholomew, K., Cordeiro, J., Swanson, S., Patterson, J., Stebbin, S., et al. (2002). Factors Affecting the Delivery of HIV/AIDS Prevention Programs by Community-Based Organisations. AIDS Education Prevention Program by Community-Based Organisation, Vol. 14 No.(3A):27-37.

Company-Community Partnerships for Health in Indonesia.(2012). Kampanye Pencegahan HIV/AIDS dan Penyalahgunaan Narokoba di Tempat Kerja http:/ /www. phi.org/ uploads/application/files/08vyv h3k6tocuy0fl4uiht7koh2b/2jbo2o7kpwke 9thc1dy1a.pdf.

Hammersley, M; Atkinson, P.(2007). Ethnography:Principles in Practice, $3^{\text {rd }}$ Edition.London: Routledge

Harapan, H., Feramuhawan, S., Kurniawan, H., Anwar, S., Andalas, M., \& Hossain, M. (2013). HIV-Related Stigma and Discrimination: A study of Health Care Workers in Banda Aceh, Indonesia. Medical Journal of Indonesia, Vol. 22 No 1: 22-29.

Indonesia Business Coalition on AIDS.(2014). Program Cerdas HIV di tempat kerja. http://ibca.or.id/id/?page_id $=22$

Kabore, I., Bloem, J., \& Etheredge, G. (2010). The Effect of Community-Based Support Services on Clinical Efficacy and HealthRelated Quality of Life in HIV/AIDS Patients in Resource-Limited Settings in Sub-Saharan Africa. AIDS Patient Care and STDs, Vol 24 No 9: 581-594.

Komisi Penanggulangan AIDS Kota Bandung. (2010). Pembentukan Forum Warga Peduli AIDS di tingkat Kecamatan dan Kelurahan. Bandung: Komisi Penanggulangan AIDS Kota Bandung.

Komisi Penanggulangan AIDS Kota Bandung. (2015). Data HIV Kota Bandung 2015. Bandung: Komisi Penanggulangan AIDS Kota Bandung.

Kurniawan, R. (2015, May 19). Ada 300 Bayi di Kota Bandung Terinfeksi HIV. Retrieved August 3, 2016, from Metro TV News: http://jabar.metrotv news.com/ read/2015/05/19/127493/ada-300-bayidi-kota-bandung-terinfeksi-hiv
Massie, R. (2012). Stigma and discrimination among the person living with HIV/AIDS: Public Sector and Community Perspective in Bitung Municipality. Buletin Penelitian Sistem Kesehatan, Vol 15 No 1: 61-65.

Michael, R., Miller, A., \& Niyigena, P. (2012). Excellent Clinical Outcomes and High Retention in Care Among Adults in a Community-Based HIV Treatment Program in Rural Rwanda. JAIDS Journal of Acquired Immune Deficiency Syndromes, e35-e42.

Miles. MB; Huberman, AM.(2009). Analisis Data Kualitatif: Buku Sumber tentang Metode-Metode Baru.Jakarta: UI Press

Nurhayati.E, S. D. (2012). Stigma dan Diskriminiasi terhadap ODHA di Kota Bandung. Retrieved August 12 , 2016, from www.unpad.ac.id: http://pustaka.unpad. ac.id/wp-content/ uploads/2013/02/ pustaka_unpad_Stigma_diskriminasi_ Odha_Kota_bandungpdf. $\bar{p} d f$

Rau, B. (2006). The Politics of Civil Society in Confronting HIV/AIDS. International Affairs, 285-295.

Reid, E. (2010). Putting Values into Practice in PNG: The Poro Sapot Project and Aid Effectiveness. e-Journal of Australian Association for the Advancement of Pacific.

Rodriguez-García, R., Bonnel, R., N'Jie, N., Olivier, J., Pascual, B., \& Wodon, Q. (2011). Analyzing Community Responses to HIV and AIDS: Operational Framework and Typology. Washington DC: World Bank.

Sadono, Dwi; Sharuddin; Yusalina; Burhanuddin; Sarianti, T. (2017). Community Satisfaction toward Posdaya Assistance Program in West Java. MIMBAR Jurnal Sosial dan Pembangunan Vol 33 No.1: 11-20 (June 2017)

Schwartländer, B., Stover, J., Hallett, T., Atun, R., Avila, C., Gouws, E., et al. (2011). Towards an Improved Investment Approach for an Effective Response to HIV/AIDS. The Lancet, 2031-2041

Shaluhiyah, Z. M. (2015). Stigma Masyarakat terhadap Orang dengan HIV/AIDS. Kesmas: Jurnal Kesehatan Masyarakat Nasional, 333-339.

Spradley, J.(2016). Ethnographic Interview. Illinois: Waveland Press

Thomas-Slayter, B. P., \& Fisher, W. F. (2011). Social capital and AIDS-resilient communities: Strengthening the AIDS response. Global Public Health, S323-S343

Van Maanen, John. (2011). Tales of the Field. On Writing Ethnography. 2nd. ed. Chicago and London: The University of Chicago Press. 